\title{
Customer Needs in Market-Driven Product Development: Product Management and R\&D Standpoints
}

\author{
Jukka Majava ${ }^{1}$, Jouko Nuottila ${ }^{1}$, Harri Haapasalo ${ }^{1}$, Kris M. Y. Law ${ }^{2}$ \\ ${ }^{1}$ Department of Industrial Engineering and Management, University of Oulu, Oulu, Finland \\ ${ }^{2}$ Department of Industrial and Systems Engineering, Hong Kong Polytechnic University, Hong Kong, China \\ Email: jukka.majava@oulu.fi
}

Received October 31, 2013; revised November 28, 2013; accepted December 5, 2013

Copyright (c) 2014 Jukka Majava et al. This is an open access article distributed under the Creative Commons Attribution License, which permits unrestricted use, distribution, and reproduction in any medium, provided the original work is properly cited. In accordance of the Creative Commons Attribution License all Copyrights (C) 2014 are reserved for SCIRP and the owner of the intellectual property Jukka Majava et al. All Copyright (C) 2014 are guarded by law and by SCIRP as a guardian.

\begin{abstract}
Meeting customer needs is considered to be vital for new product success. This study explores customer need identification and related challenges in product management and research and development (R\&D) in a market-driven context, where a large number of customers exist. This paper reviews the literature on customer interaction and needs in a product development context. Despite the rich literature, product management and $R \& D$ angle have not been sufficiently addressed. Thus, customer need identification and challenges from product management and R\&D managers' perspectives are studied in two new product development (NPD) projects: one in business-to-business (B2B) and the other in business-to-consumer (B2C) market. While differences between B2B and B2C markets exist, the results indicate that product management professionals must collaborate with various stakeholders and utilize many information sources to obtain and interpret diverging customer needs. Recommended practices for companies to tackle various customer-need related challenges include systematic ways of working, small cross-functional teams in product definition, and avoiding early handovers between product management and $R \& D$. Besides internal collaboration, product management and $R \& D$ professionals should aim for some direct contact with selected external customers to clarify the real and project specific needs, and to build overall understanding about customers.
\end{abstract}

\section{KEYWORDS}

Product Development; New Product Development (NPD); Product Management; Customer Need; Market-Driven; Research and Development (R\&D); Stakeholder

\section{Introduction}

Customers are one of the key sources for new product development projects, and understanding customer needs is required to ensure product success [1-3]. While customer involvement in product development may not always result in the desired results, interaction with customers can reduce uncertainty and develop foresight to meet their future needs better [4]. Customer orientation is a key element of a market orientation strategy [5], and various methods to identify customer needs have been proposed [6,7]. However, global markets with a large number of customers necessitate distinctive efforts to understand customer needs for new product development (NPD) purposes.
Product management aims for customer satisfaction and a long-term company value. Product management tasks include the identification of both stated and unstated customer needs, road mapping and strategic vision. More operational tasks include, for instance, release planning, requirement elicitation, prioritization and management $[8,9]$. Requirement elicitation focuses on identifying information sources, such as customers and other stakeholders, and requirement discovery by using various techniques [10-12].

In a market-driven context, a company has numerous customers who make decisions regarding the product's functionality, instead of only one. Requirements flow continuously from various internal and external stakeholders 
and sources $[13,14]$. The special needs of market-driven product development include balancing different requirement types, market-pull and technology-push trade-off, and release planning and requirement selection [15].

Despite the rich literature on customer needs, e.g. [3], insufficient attention has been paid to how product management and research and development (R\&D) professionals responsible for defining requirements and product features identify customer needs in a market-driven context. This paper studies customer need discovery in market-driven product development. The research questions are framed as follows:

1) How do product management and R\&D managers identify customer needs in market-driven product development?

2) What customer need for related challenges that exist for product management and R\&D managers in marketdriven product development?

The research questions are addressed through the literature and an empirical study. The literature review focuses on customer interaction in product development and customer need identification. The empirical study covers the industry practices at a managerial level through case projects in selected product development organizations. Finally, conclusions are presented after the data analysis.

\section{Literature}

\subsection{Product Development and Customer Interaction}

Product development transforms market opportunities into production, sales and the delivery of products [16]. Product development projects include R\&D, break-through, platform and derivative projects, incremental improvements and fundamentally new products [7,17]. Small change projects require customer interaction to acquire tacit knowledge about needs and current product shortages. On the other hand, in NPD for existing markets, customers' unmet tacit needs must be translated into features without an existing product. In NPD for new markets, customer interaction often takes place only when a prototype is available [18].

Product development can also be categorized into design by, design with and design for customers. In the design for approach, products are designed for the customers' behalf, similar to market-driven product development $[15,19]$. In the design with approach, the customers can give feedback on design proposals, whereas in the design by approach customers actively participate in the design of their own product [19]. In addition to co-creation, the customers' role is also seen as active in open innovation [20,21].

Bidirectional communication and joint problem solving with customers enable the business to understand customer needs that are difficult to express [22]. Product users must always be considered, but other types of customers and stakeholders, also ones who are beyond the direct customers, may need to be taken into account [3, $7,23]$. A customer profile matrix with different types of customers, such as lead users close to the company, has been proposed for choosing customers to interact with $[1,24,25]$. The stakeholders also depend on the drivers of product development effort [26,27].

\subsection{Customer Needs and Identifying Them}

Customers have needs related to their problems and what products enable them to do $[3,28]$. Needs depend on a situation, have different priorities, and can be identified without knowing how to address them $[7,28,29]$. In quality function deployment, a customer's need is the customer's own description of a desired product benefit [29]. Customer needs often correlate with the customer's values and behavior [28]. A deep understanding of needs helps when selecting the best technology and features for products [3].

The literature typically divides marketing information into primary and secondary data. The former is gathered to serve a specific purpose, whereas the latter refers to existing information, which can be used to enhance market knowledge [30,31]. The methods for gathering customer needs include interviews, observations, focus groups, becoming a user, customer advisory boards, websites, panels and groups. Furthermore, brainstorming, innovation summits, customer integration into a product development team, discussions with customers, ethnography, identifying lead users, and market surveys are used [1,3,6,7,14, 25,29,31,32].

Customer studies can be quantitative or qualitative. Quantitative research enables numerical analysis and presentation and has a good bias resistance, whereas qualitative techniques provide insights, ideas and understanding about problems [30,32]. Qualitative techniques are commonly used in customer need identification, and a typical study includes interviewing between ten and fifty customers. More than one person should interpret the data, since it can be translated in many ways $[7,29]$. The needs and problems should be expressed in the customer's language, clearly, concisely, and in a contextually specific way [3].

Various challenges exist in customer need identification and gathering. Identifying real customer needs requires understanding real problems and what products enable customers to do [6]. Customers often cannot articulate their requirements, have unprofitable requests, are unaware of possibilities, propose incremental improvements they believe suppliers will implement, and propose the same things to competitors [33]. Obtaining tacit and complex knowledge from customers is hard, and organi- 
zational boundaries make it even harder [4,34]. In business-to-business (B2B) markets, a large number of parties must be considered, such as users, deciders, buyers and gatekeepers [14,28]. The business-to-consumer (B2C) market challenges, in turn, include having a huge number of individual customers and understanding the behaviors of different consumer groups [14,28].

\section{Method}

The empirical study is based on two case studies [35]. Mid-level managers were interviewed regarding their perceptions towards customer need identification and the challenges faced. The 11 managers were involved in both product management and R\&D (Table 1 ). The case companies were chosen from the information and communications technology (ICT) industry, one from the B2B market and the other from the B2C market. The companies were based in Northern Europe.

Semi-structured interviews were used to gain insights into the cases and the respondents' thoughts regarding the study's topics. The interviews lasted around one hour, and they were recorded and transcribed for analysis. The first phase of the interviews included questions on product development in the company, the case project, and its stakeholders and customers. After that, the questions specifically addressed customer need identification, which was the main focus of this study. The specific questions included the following: how were customer needs identified? Did customer collaboration take place and how? Were any systematic methods used? Were the following methods used: surveys, interviews, observation, web sites, focus groups, customer discussions and workshops, identifying lead users, becoming a user, customer integration into product development team? What were the good practices and key challenges in customer need identification?

The data analysis followed the process described in [36]. The analysis was conducted by using the qualitative

Table 1. List of interviewees.

\begin{tabular}{ccc}
\hline Case & Interviewee role & Experience (years) \\
\hline$\alpha$ & Product manager & +10 \\
$\alpha$ & Concept manager & +10 \\
$\alpha$ & Product manager & +15 \\
$\alpha$ & Software product owner & +10 \\
$\alpha$ & Program manager & +15 \\
$\alpha$ & Project manager & +10 \\
$\beta$ & Product management head & +20 \\
$\beta$ & Product manager & +20 \\
$\beta$ & Product manager & +25 \\
$\beta$ & Technical manager & +25 \\
$\beta$ & Platform design manager & +20 \\
\hline
\end{tabular}

approach of reading the interviews several times, each time going deeper into the data to discover connections, patterns and juxtapositions. Emerging patterns were structured into more generic categories that helped define the key concepts and issues.

\section{Empirical Results}

\subsection{Case $\alpha$}

Case $\alpha$ is a software project from a large ICT company in a global B2C market. The project involved a software release program, starting from concept development and ending at launch. In addition, the software platform architecture of the final products was renewed. The final products were targeted to a specific consumer group, but also wider market, distribution partners, and geographical requirements were considered. Contrary to earlier projects, the product definition started from scratch, and only a core feature set was defined for sales start. In addition, work practices in product development were renewed. This entailed, for example, specifying the testing of new features already in their definition phase, and changing requirement and error database structures to support the new operation mode. The project can be considered a market-driven product development project with a large number of customers to be served. In terms of size and newness, it was considered a large-scale, radical project. The development model was based on agile principles.

\subsection{Case $\beta$}

Case $\beta$ is a hardware and embedded software project from a large ICT company in a global B2B market. The project included the development of a new product platform to replace the current solution. The platform was used by the company's business lines, which productize final products to external customers. The final products were targeted to selected customers, but a wider market, including different technical and geographical requirements, was also considered. The product was highly complex, and therefore the development took a relatively long time. The project can be classified as a market-driven product development project with a large number of customers to be served. It represented a typical platform development project for the company, despite being somewhat larger than usual. The development model was based on concurrent engineering for the hardware and agile principles for the software.

\subsection{Internal Stakeholders and Customer Need Identification in Case $\alpha$}

In case $\alpha$, several key stakeholders dealing with customer needs were recognized. These stakeholders are presented in Table 2. 
Table 2. Key internal stakeholders for customer needs in case $\alpha$.

\begin{tabular}{ll}
\hline \multicolumn{1}{c}{ Stakeholder } & \multicolumn{1}{c}{ Role } \\
\hline Product management & Combines customer needs from the stakeholders and information sources into customer voice supported by own vision \\
R\&D & Turns customer needs and requirements into technical solutions and features \\
Marketing & Organizes market and consumer studies and creates target user profiles \\
Sales unit & Provides customer needs from local markets \\
Customer account team & Provides direct customers’ needs and facilitates collecting them \\
User experience team & Provides end-user usability aspects and research \\
\hline
\end{tabular}

Both the product management and R\&D representatives saw that the customer voice into product development came from product management. Product management, in turn, received customer input from marketing, sales units, customer account teams, and other regional contacts. These groups were seen as the key internal stakeholders for identifying customer needs. However, product management's own vision of needs was also emphasized, and co-operation with marketing, for example, was seen as a dialogue. On the other hand, R\&D representatives saw that user experience teams also provide consumer (end-user) viewpoints during development, since the teams understand the product functionalities from a usability perspective and carry out end-user research.

Various methods were used for identifying customer needs. Quantitative studies had been used in the company earlier, but as one interviewee pointed out, "they mostly reflected the existing needs." Current studies were mainly qualitative, and customer co-creation had also been started with promising results in identifying future needs. In the project, the methods used for identifying customer needs included

- interviews;

- market surveys;

- user studies;

- observations;

- web sites;

- focus groups;

- workshops;

- lead users; and

- becoming a user.

End-user interviews in the target markets were the main method used. Different types of market and user surveys were considered valuable as well. Observations, in turn, revealed "if the user is struggling or just telling us what we want to hear". Web sites provided a source of consumer information, but were also used for internal communities and competitor information. Focus groups and workshops were also utilized to some extent, but in addition to their benefits, there was also doubt about whether individual opinions were influenced by the group. Lead users were identified in the target markets, and the employees tried to become users themselves.
Customer needs were collected mostly from consumers, and the product was introduced to the direct customers (distribution partners) only when market entry was close. The relevance of each existing customer requirement was checked in iterative discussions with stakeholders who were close to the customers. This was important, since the target was to start sales with only a minimal set of features. The requirement databases and old products were checked to identify critical features that could not be left out. In the later project stages, internal and external end-user testing, error databases, and direct customer approvals provided information on how the product met customer needs.

\subsection{Internal Stakeholders and Customer Need Identification in Case $\beta$}

In the interviews, four key internal stakeholders for customer needs were recognized (Table 3).

As in case $\alpha$, customer voice into product development was considered to come from product management. In addition to external customers, customer input was received from business lines and customer account teams. A systematic process for collecting customer needs already existed in the company, but some respondents pointed out that "there is also room for improvement". Product management's own "gut feeling" was seen as important, since "customer views are not necessarily very structured". The customer need identification methods included

- in-depth interviews;

- customer meetings;

- workshops;

- customer visits to the company; and

- market reports.

Interviews were clearly seen as the main method for customer need identification; around twenty customers were interviewed for the project. Product management had selected the interviewed customers from the lead customer group defined by company management. In addition to sales volumes, product management's selections covered different types of customers, all three business lines, and various geographical and technical aspects. The interviewees included key customer representatives related to the product under discussion. The interviews 
Table 3. Key internal stakeholders for customer needs in case $\beta$.

\begin{tabular}{|c|c|}
\hline Stakeholder & Role \\
\hline Product management & Combines customer needs from the stakeholders and information sources into customer voice supported by own vision \\
\hline $\mathrm{R} \& \mathrm{D}$ & Turns customer needs and requirements into technical solutions and features \\
\hline Customer account team & Provides customer needs from local markets, direct customers' needs and facilitates collecting them \\
\hline
\end{tabular}

were conducted by a product manager and a technical architect. In addition, meetings and workshops were organized at the customers' facilities, and key customers also visited the company to discuss their special needs.

The customers' fundamental needs were seen as not changing frequently, but, for example, new types of technical trends were seen as creating new customer requirements. Market reports were used to some extent to anticipate forthcoming requirements. In addition, the company's customer needs database, which mainly included issues related to current products, was checked for future related needs. The internal customers' needs were taken into account by inviting participation from business lines, production and customer operations in the project organization. Internal discussions on needs were considered essential before the actual requirements were entered into the tools.

\subsection{Challenges Related to Customer Needs in Case $\alpha$}

In case $\alpha$, product management representatives raised various customer need related challenges. First of all, focusing on target customer needs while simultaneously fulfilling the needs of a larger customer base was considered difficult. The target markets and consumers were clearly defined, but other types of consumers with different needs were also expected to purchase the product. Moreover, while consumers had the highest priority, direct customers' needs also had to be considered. In previous projects, the company tried to fulfill too many needs, which resulted in delays and feature removals. Understanding current customer needs, reacting to feedback, and anticipating changes and future needs were seen as challenging. Furthermore, while product managers defined the customer experience, they had to rely on other stakeholders for the customer needs collection, and then interpret the provided information. One interviewee saw that a large amount of customer information exists, but "how it is used, analyzed, and put together is more based on feelings than being systematic". Distributing information about target consumers to various internal stakeholders, including software developers, was also seen as challenging. On the other hand, the product managers tried to become product users themselves, but acknowledged that they did not match the target user profile. Finally, it was pointed out that customers do not know all the possibilities, and thus product decisions cannot be based only on customer needs.

The $R \& D$ representatives saw the challenges somewhat differently. First of all, understanding customer needs for technical products required many types of dialogues, and hundreds of people in different teams were involved in processing the needs and requirements. Whereas the previous projects tried to fulfill too many needs, the identification of critical customer needs was seen as difficult. In addition, turning customer needs into product features while taking technical and price constraints into account was considered very challenging. The R\&D representatives also acknowledged that their needs and product use differed from the target users' needs and use. Furthermore, some developers did not use the product and features they developed. Using the product fulltime during development to simulate real use was also considered difficult. Finally, customer feedback during development came late; the reported problem could have already been fixed. The challenges are summarized in Table 4.

\subsection{Challenges Related to Customer Needs in Case $\beta$}

As in case $\alpha$, the product management representatives saw that focusing on the target customers' needs while simultaneously fulfilling the needs of a larger customer base was challenging. In addition, too many focus areas were considered to exist, despite management's prioritization. The customers' organizations were large and global, and had different needs even within a single organization. Needs also differed among the customers, but collecting hundreds of companies' needs was impossible. The product also had to fulfill the internal customers' (business lines) needs, but the internal customers were perceived as often unaware of their own and their external customers' long-term needs. Organizational changes during the project resulted in changes among the internal customers and their requirements. Information on customer needs was partly lost, and the information changed inside the company. For instance, one product management representative stated that customer account teams sometimes provided totally opposite answers on customer needs than the customers themselves did. Furthermore, collecting customer needs was not always considered to be systematic. On the other hand, customers were seen to 
Table 4. Challenges related to customer needs in case $\alpha$.

\begin{tabular}{|c|c|}
\hline Product management & $\mathrm{R} \& \mathrm{D}$ \\
\hline Diverse needs of target customers and larger customer base & A large number of people involved in processing the needs and requirements \\
\hline Meet both direct customers' and end-users’ needs & Identifying critical customer needs \\
\hline Understanding short-term needs and reacting to feedback & $\begin{array}{l}\text { Turning customer needs into product features while considering technical and } \\
\text { price constraints }\end{array}$ \\
\hline Understanding changes and long-term needs & $\begin{array}{l}\text { Development team's needs and product use differ from target consumers' } \\
\text { needs and use }\end{array}$ \\
\hline Interpreting information on customer needs provided by stakeholders & Developers not using the product and feature they develop \\
\hline Customer information not used systematically & Not possible to use the product full-time to simulate real use \\
\hline $\begin{array}{l}\text { Distributing information about target consumers inside the } \\
\text { organization }\end{array}$ & Late customer feedback \\
\hline \multicolumn{2}{|l|}{$\begin{array}{l}\text { Development team's needs and product use differ from target } \\
\text { consumers' needs and use }\end{array}$} \\
\hline Customers unaware of possibilities & \\
\hline
\end{tabular}

be short-term focused and unable to articulate their longterm needs. To avoid cannibalizing existing products, details on the future product could not be communicated early. This prevented specific discussions, and therefore customer comments and feedback were sometimes suspected to be vague. The customers' existing products also had to be taken into account. Finally, due to the long development time, the customers' needs changed during the project.

The R\&D representatives also pointed out many customer need related challenges. First of all, deciding which needs to fulfill and which to optimize the platform for was considered challenging. The customers' large size and global presence caused big differences in needs. The prioritization of needs was seen as missing sometimes, and internal customers were considered as focusing only on their own needs. Customers were seen to be shortterm focused and unable to articulate their long-term needs. From a platform development perspective, the needs were received late, and they were often too discrete and shortterm, representing problems related to current products in the market. The needs were thought to be based on what customers had been told and offered, and the requested solutions conflicted with the platform's goals. It was also acknowledged that information on customer needs was lost inside the company, and communication in converting the needs into requirements and technical proposals was seen as difficult. Finally, customer requirements were considered to be too detailed, and requirement definitions focused too much on the current technical implementation. Table 5 summarizes the challenges.

\section{Discussion}

This study indicates that customer need identification in market-driven product development involves many internal stakeholders, utilization of various methods, and several challenges. Table 6 summarizes and compares the key findings from the case projects.

\subsection{Key Internal Stakeholders for Customer Needs}

Customer need identification in market-driven product development involves collaboration with several stakeholders and utilizing many information sources. In addition, needs also differ significantly within a large customer base. Product management collaborates with various stakeholders, interprets the provided customer information, and works together with R\&D in processing the needs into requirements and product features. Furthermore, product management's own vision is needed to turn tacit information into explicit requirements, because customers can rarely articulate their long-term needs.

Some differences in key internal stakeholders were identified between the case projects. In case $\alpha$, marketing was the organizer of the market and consumer studies and the architect of the target user profiles. Sales units obtained local customer needs, customer account teams provided direct customers' needs and facilitated collecting them, and the user experience team contributed enduser usability aspects and research to support product development. On the other hand, in case $\beta$, business lines provided internal and external customers' needs, and customer account teams delivered local market and direct customers' needs, and facilitated gathering them.

\subsection{Customer Need Identification Methods}

Interviews were found to be the most significant customer need identification method in both case projects. Direct customer contacts were seen as important; not only for clarifying the project's specific needs, but also to build understanding about customers overall. In addition, market surveys, reports and customer workshops were also utilized to some extent in both cases.

In case $\alpha$, sufficient understanding about consumers was further aimed for with the help of user studies, observations, web sites, focus groups, identifying lead users, 
Table 5. Challenges related to customer needs in case $\boldsymbol{\beta}$.

\begin{tabular}{|c|c|}
\hline Product management & $\mathrm{R} \& \mathrm{D}$ \\
\hline Diverse needs of target customers and larger customer base & Deciding which needs to fulfill and which to optimize the platform for \\
\hline Too many focus areas & Big differences in needs within and between customer organizations \\
\hline Not possible to collect information from all customers & Internal customers’ narrow focus \\
\hline $\begin{array}{l}\text { Internal customers not aware of their own and external customers' } \\
\text { long-term needs }\end{array}$ & Customers are short-term focused and cannot articulate long-term needs \\
\hline Change of internal customers and their needs due to organization changes & Needs received too late, too discrete, and short-term \\
\hline Information on customer needs is lost and changed inside the organization & Needs are based on what customers have been told and offered \\
\hline Customer needs are not collected systematically & Customer needs conflict with platform goals \\
\hline $\begin{array}{l}\text { Customers are short-term focused and cannot articulate their long-term } \\
\text { needs }\end{array}$ & Information on customer needs is lost and changed inside the organization \\
\hline $\begin{array}{l}\text { Not possible to discuss future products with customers to get specific } \\
\text { feedback }\end{array}$ & $\begin{array}{l}\text { Communication challenges in converting needs into requirements and } \\
\text { technical solutions proposals }\end{array}$ \\
\hline Existing products have to be taken into account in customer needs & Requirements definition focuses on current technical implementation \\
\hline Customer needs change during the project & \\
\hline
\end{tabular}

Table 6. Summary and comparison of the case projects.

\begin{tabular}{|c|c|c|}
\hline & Case $\alpha$ & Case $\beta$ \\
\hline $\begin{array}{l}\text { Business and product } \\
\text { natures }\end{array}$ & $\begin{array}{l}\text { B2C market in NPD-intensive ICT industry, tangible } \\
\text { products for which software plays a key role }\end{array}$ & $\begin{array}{l}\text { B2B market in NPD-intensive ICT industry, tangible products } \\
\text { with both hardware and software }\end{array}$ \\
\hline $\begin{array}{l}\text { Key internal } \\
\text { stakeholders for } \\
\text { customer needs and } \\
\text { their roles }\end{array}$ & $\begin{array}{l}\text { Product management: combines customer needs from the } \\
\text { stakeholders and information sources into customer voice } \\
\text { supported by own vision; } \\
\text { R\&D: turns customer needs and requirements into technical } \\
\text { solutions and features; } \\
\text { Marketing: organizes market and consumer studies and } \\
\text { creates target user profiles; } \\
\text { Sales unit: provides customer needs from local markets; } \\
\text { Customer account team: provides direct customers' needs } \\
\text { and facilitates collecting them } \\
\text { User experience team: provides end-user usability aspect and } \\
\text { research }\end{array}$ & $\begin{array}{l}\text { Product management: combines customer needs from the } \\
\text { stakeholders and information sources into customer voice sup- } \\
\text { ported by own vision; } \\
\text { R\&D: turns customer needs and requirements into technical } \\
\text { solutions and features; } \\
\text { Business line: provides internal and external customers’ needs; } \\
\text { Customer account team: provides customer needs from local } \\
\text { markets, direct customers' needs and facilitates collecting them }\end{array}$ \\
\hline $\begin{array}{l}\text { Customer need } \\
\text { identification } \\
\text { methods }\end{array}$ & $\begin{array}{l}\text { Interviews; market surveys; user studies; observations; web } \\
\text { sites; focus groups; workshops; lead users; becoming a user }\end{array}$ & $\begin{array}{l}\text { In-depth interviews; customer meetings; workshops; customer } \\
\text { visits to the company; market reports }\end{array}$ \\
\hline $\begin{array}{l}\text { Key challenges faced } \\
\text { by product } \\
\text { management }\end{array}$ & $\begin{array}{l}\text { Diverse needs of target customers and larger customer base; } \\
\text { Interpreting information on customer needs provided by } \\
\text { stakeholders; } \\
\text { Anticipating future customer needs }\end{array}$ & $\begin{array}{l}\text { Diverse needs of target customers and larger customer base; } \\
\text { Information on customer needs is lost and changed inside the } \\
\text { organization; } \\
\text { Customers are short-term focused and cannot articulate their } \\
\text { long-term needs }\end{array}$ \\
\hline $\begin{array}{l}\text { Key challenges faced } \\
\text { by R\&D }\end{array}$ & $\begin{array}{l}\text { A large number of people involved in processing needs and } \\
\text { requirements; } \\
\text { Identifying critical customer needs; } \\
\text { Development team's needs and product use differ from target } \\
\text { consumers' needs and use }\end{array}$ & $\begin{array}{l}\text { Deciding which needs to fulfill and to optimize the platform for; } \\
\text { Big differences in needs within and between customer } \\
\text { organizations; } \\
\text { t Information on customer needs is lost and changed inside the } \\
\text { organization }\end{array}$ \\
\hline
\end{tabular}

and becoming a user of the product under development. Case $\beta$, in turn, involved a business-to-business market; thus, meetings with select customers were considered important.

\subsection{Key Challenges}

The results revealed many challenges related to customer needs. Out of the identified challenges, the diverse needs of the target customers and a larger customer base were seen as key issues from product management's perspective in both cases. In addition, anticipating and understanding the customers' long-term needs was seen as challenging. In case $\alpha$, the product management representatives felt that interpreting the customer needs as provided by the stakeholders was difficult. Case $\beta$ revealed a similar challenge; the customer needs information was seen as lost and changed inside the organization. 
Understanding customer needs is not solely product management's responsibility; R\&D must also understand these needs to ensure optimal technical solutions and the right design decisions. Identifying the most important needs that a solution must fulfill was seen as a key challenge from the $R \& D$ perspective in both cases. In case $\alpha$, it was pointed out that a large number of people can be involved in processing the needs and requirements. In case $\beta$, information about customer needs was seen as lost and changed inside the organization. Finally, in case $\alpha$, the R\&D team's needs and product use differed from the target consumers' needs and use, which made "becoming a user" difficult. In case $\beta$, the $\mathrm{R} \& \mathrm{D}$ representatives saw the differences in needs within and between customer organizations to be one of the key challenges.

\subsection{Theoretical Implications}

The literature presents various methods for identifying customer needs for product development purposes [3,7, 29]. However, a large customer base in a market-driven context complicates customer need identification considerably. In addition, new product development requires tacit knowledge about needs and translating the needs into product features [18]. Despite many studies on customer needs in NPD, particularly product management standpoint has been insufficiently addressed. This study provides new information on customer need identification and related challenges from a product management and R\&D managers' perspective.

The results of this study indicate that, in terms of customer needs, the role of product management includes collaborating with various stakeholders to identify customer needs and, together with $\mathrm{R} \& \mathrm{D}$, to further process them into requirements, technical solutions and product features. Internal and external collaboration is highlighted by [9], and the literature also discusses the challenges related to customer need identification and gathering e.g. $[4,6,33]$. Nonetheless, this study revealed challenges that may be specific to market-driven product development. These include acquiring and considering the diverse needs of both the target customers and a larger customer base, and interpreting the customer needs information provided by the stakeholders.

Finally, the results also highlight different practices in business-to-consumer and business-to-business markets. In case $\alpha$, which was from B2C market, several common methods were utilized for identifying customer needs e.g. $[1,3,14,25]$, and the information was provided mainly by internal stakeholders. Consumer profiles were created to understand the target customers' needs. On the other hand, $\mathrm{B} 2 \mathrm{~B}$ market case $\beta$ involved substantially fewer information collection methods, and the product management and R\&D professionals were in contact with selected customers more frequently than in case $\alpha$. The customer profile matrix [24] type of approach was used for customer selection.

\subsection{Managerial Implications}

Understanding customer needs is important to ensure product success in today's markets, where differentiation is increasingly difficult. However, the market-driven context poses tough challenges for managers involved in product development. First, no single customer exists who decides on the product's functionality, and needs can differ significantly between customers. It is impossible to develop solutions that tackle diverse requirements without understanding real customer needs; which needs to fulfill and which to optimize the solution for. Furthermore, a large number of people can be involved in processing the needs and requirements. A lot of interpretation is needed, and information about customer needs may be lost or changed inside the organization.

In the market-driven context, product management must effectively collaborate with several stakeholders and utilize many information sources to identify customer needs. Furthermore, product management and R\&D professionals must turn the needs into the right requirements and product features. Managers ought to understand that the use of requirement engineering software tools alone will not solve the problems. A systematic way of working and effective co-operation among product management, R\&D and other internal stakeholders is needed. Customer needs should not just be converted into detailed requirements, which are then thrown into R\&D for implementation. Product developers must also understand the customers' needs to provide solutions that can meet diverse needs.

Recommended practices include working in small cross-functional teams during product definition and avoiding handovers between product management and R\&D that are too early. In the early project phase, big teams must be avoided to ensure clear responsibilities and clarifying the customers' needs instead of just assuming what they are. Using tools, such as a customer profile matrix [24], is recommended to ensure that customers with different needs are considered. In addition, the relevance of the customers' requirements should sometimes be questioned to reveal the real needs. Besides internal inputs, the product management and R\&D professionals should aim for direct contact with external customers to acquire understanding so that they are able to develop solutions that meet a large variety of needs in a market-driven environment.

\section{Conclusions}

Meeting customer needs is a key prerequisite for new product success. However, understanding these needs is difficult, and increasingly complex global markets neces- 
sitate distinctive efforts to identify and gather the needs for product development purposes. Many challenges exist, especially in a market-driven context, where a company typically has a large number of customers instead of only one who decides on product functionality. This study explores customer need identification, related challenges in product management and $\mathrm{R} \& \mathrm{D}$ in market-driven product development.

Despite rich literature on product development and customer needs, product management viewpoint has been inadequately addressed. While differences between B2B and $\mathrm{B} 2 \mathrm{C}$ markets exist, the results indicate that product management's role includes collaborating with various stakeholders and using several information sources to obtain customer needs. However, the needs diverge significantly in a large customer base, and understanding them requires a lot of interpretations. A number of people participate in processing needs, and information can be lost or changed inside organizations. Yet, requirement engineering software tools alone cannot solve the problems. Recommended practices include a systematic way of working and small cross-functional teams during product definition. Early handovers between product management and R\&D should be avoided. In addition to internal collaboration, product management and R\&D professionals should aim for some direct contact with selected external customers, not only for clarifying the real and project specific needs, but also for building overall understanding to meet diverse needs better.

The limitations of this paper include the fact that only two case projects were studied. Aside from addressing this limitation, recommended future research could include how the study findings might apply to different types of firms and industries.

\section{REFERENCES}

[1] I. Alam, "Interacting with Customers in the New Product Development Process,” In: K. B. Kahn, Ed., The PDMA Handbook of New Product Development, 2nd Edition, John Wiley \& Sons, Inc., Hoboken, 2005, pp. 249-262.

[2] W. M. Cohen, R. R. Nelson and J. P. Walsh, "Links and Impacts: The Influence of Public Research on Industrial R\&D,” Management Science, Vol. 48, No. 1, 2002, pp. 123. http://dx.doi.org/10.1287/mnsc.48.1.1.14273

[3] A. Griffin, "Obtaining Customer Needs for Product Development,” In: K. B. Kahn, Ed., The PDMA Handbook of New Product Development, 2nd Edition, John Wiley \& Sons, Inc., Hoboken, 2005, pp. 211-227.

[4] C. A. Un, A. Cuervo-Cazurra and K. Asakawa, "R\&D Collaborations and Product Innovation," Journal of Product Innovation Management, Vol. 27, No. 5, 2010, pp. 673-689. http://dx.doi.org/10.1111/j.1540-5885.2010.00744.x

[5] J. C. Narver and S. F. Slater, "The Effect of a Market Orientation on Business Profitability,” Journal of Mar- keting, Vol. 54, No. 4, 1990, pp. 20-35. http://dx.doi.org/10.2307/1251757

[6] R. G. Cooper, "Winning at New Products: Creating Value Through Innovation," 4th Edition, Basic Books, New York, 2011.

[7] K. Ulrich and S. D. Eppinger, "Product Design and Development,” 5th Edition, McGraw Hill, New York, 2012.

[8] D. R. Lehmann and R. S. Winer, "Product Management," 3rd Edition, McGraw-Hill, New York, 2002.

[9] A. Maglyas, U. Nikula and K. Smolander, "What Do Practitioners Mean When They Talk about Product Management?” Proceedings of the 20th IEEE International Requirements Engineering Conference, Chicago, 24-28 September 2012, pp. 261-266.

[10] A. M. Hickey and A. M. Davis, "A Unified Model of Requirements Elicitation," Journal of Management Information Systems, Vol. 20, No. 4, 2004, pp. 65-84.

[11] M. Mottonen, J. Harkonen, P. Belt, H. Haapasalo and J. Simila, "Managerial View on Design for Manufacturing," Industrial Management and Data Systems, Vol. 109, No. 6, 2009, pp. 859-872. http://dx.doi.org/10.1108/02635570910968081

[12] I. Sommerville, "Integrated Requirements Engineering: A Tutorial,” IEEE Software, Vol. 22, No. 1, 2005, pp. 16-23. http://dx.doi.org/10.1109/MS.2005.13

[13] T. Gorschek, A. Gomes, A. Pettersson and R. Torkar, "Introduction of a Process Maturity Model for Market- Driven Product Management and Requirements Engineering,” Journal of Software: Evolution and Process, Vol. 24, No. 1, 2012, pp. 83-113. http://dx.doi.org/10.1002/smr.535

[14] P. Kotler and K. L. Keller, "Marketing Management," 13th Edition, Pearson Prentice Hall, Upper Saddle River, 2009.

[15] N. D. Fogelstrom, T. Gorschek, M. Svahnberg and P. Olsson, "The Impact of Agile Principles on Market-Driven Software Product Development," Journal of Software Maintenance and Evolution, Vol. 22, No. 1, 2010, pp. 5380. http://dx.doi.org/10.1002/spip.420

[16] V. Krishnan and K. Ulrich, "Product Development Decisions: A Review of the Literature,” Management Science, Vol. 47, No. 1, 2001, pp. 1-21. http://dx.doi.org/10.1287/mnsc.47.1.1.10668

[17] M. A. Schilling and C. W. L. Hill, "Managing the New Product Development Process: Strategic imperatives," IEEE Engineering Management Review, Vol. 26, No. 4, 1998, pp. 55-68.

[18] C. A. Un and A. Cuervo-Cazurra, "Interactions with Custo-mers for Innovation,” In: L. A. Costanzo and R. B. MacKay, Eds., Handbook of Research on Strategy and Foresight, Edward Elgar Publishing Limited, Northampton, 2009. http://dx.doi.org/10.4337/9781848447271.00029

[19] M. A. Kaulio, "Customer, Consumer and User Involvement in Product Development: A Framework and a Review of Selected Methods," Total Quality Management, Vol. 9, No. 1, 1998, pp. 141-149.

http://dx.doi.org/10.1080/0954412989333

[20] H. W. Chesbrough, “Open Innovation: The New Impera- 
tive for Creating and Profiting from Technology,” Harvard Business School Publishing Corporation, Boston, 2003.

[21] C. K. Prahalad and V. Ramaswamy, "The Future of Competition: Co-Creating Unique Value with Customers,” Harvard Business School Publishing, Boston, 2004.

[22] J. M. Bonner, "Customer Interactivity and New Product Performance: Moderating Effects of Product Newness and Product Embeddedness," Industrial Marketing Management, Vol. 39, No. 3, 2010, pp. 485-492. http://dx.doi.org/10.1016/j.indmarman.2008.11.006

[23] B. Hillebrand and W. G. Biemans, "Dealing with Downstream Customers: An Exploratory Study,” Journal of Business and Industrial Marketing, Vol. 26, No. 2, 2011, pp. 72-80. http://dx.doi.org/10.1108/08858621111112258

[24] G. Burchill and C. Hepner Brodie, "Voices into Choices: Acting on the Voice of the Customer," Center for Quality of Management, Madison, 2005.

[25] E. von Hippel, "Lead Users: A Source of Novel Product Concepts,” Management Science, Vol. 32, No. 7, 1986, pp. 791-805. http://dx.doi.org/10.1287/mnsc.32.7.791

[26] J. Majava, H. Haapasalo, P. Belt and M. Mottonen, "Product Development Drivers in Literature and Practice," International Journal of Product Development, Vol. 18, No. 6, 2013, pp. 512-530.

[27] J. Majava, J. Harkonen and H. Haapasalo, “The Relations between Stakeholders and Product Development Drivers: Practitioners' Perspectives," International Journal of Innovation and Learning, in press.
[28] D. Peppers and M. Rogers, "Managing Customer Relationships: A Strategic Framework,” 2nd Edition, John Wiley \& Sons, Inc., Hoboken, 2011.

[29] A. Griffin and J. Hauser, "The Voice of the Customer," Marketing Science, Vol. 12, No. 1, 1993, pp. 1-27. http://dx.doi.org/10.1287/mksc.12.1.1

[30] R. Birn, "The International Handbook of Market Research Techniques,” Kogan Page, London, 2002.

[31] M. D. Hutt and T. W. Speh, "Business Marketing Management: A Strategic View of Industrial and Organizational Markets," 6th Edition, The Dryden Press, Forth Worth, 1998.

[32] P. M. Chisnall, “Strategic Business Marketing,” 3rd Edition, Prentice Hall, London, 1995.

[33] E. Berggren and T. Nacher, "Introducing New Products Can Be Hazardous to Your Company: Use the Right New-Solutions Delivery Tools," Academy of Management Executive, Vol. 15, No. 3, 2001, pp. 92-101. http://dx.doi.org/10.5465/AME.2001.5229638

[34] I. Nonaka and H. Takeuchi, "The Knowledge-Creating Company: How Japanese Companies Create the Dynamics of Innovation,” Oxford University Press, New York, 1995.

[35] R. K. Yin, "Case Study Research: Design and Methods," 3rd Edition, Sage Publications, Thousand Oaks, 2003.

[36] K. M. Eisenhardt, "Building Theories from Case Study Research,” Academy of Management Review, Vol. 14, No. 4, 1989, pp. 532-550. 